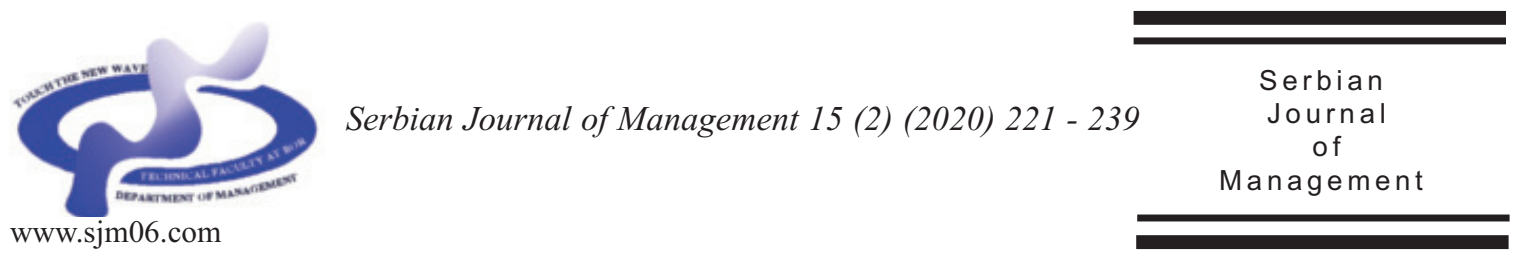

\title{
E-BUSINESS CAPABILITIES AND INNOVATION PERFORMANCE: THE MEDIATING EFFECT OF KNOWLEDGE MANAGEMENT STRATEGIES
}

\author{
Jose Arias-Pérez*, Esteban López-Zapata and Andrea Echeverri-Bedoya \\ Department of Administrative Sciences, \\ Universidad de Antioquia, Calle 67 No. 53 - 108, 13-106, Medellín, Colombia
}

(Received 05 February 2019; accepted 20 October 2019)

\begin{abstract}
The aim of this paper is to analyze the mediating effect of the knowledge management strategies on the relationship between e-business capabilities and innovation performance. The research model was tested with a sample of 102 firms belonging to IT intensive sectors, located in an emerging country that is a regional leader in terms of e-business adoption. Structural equations by the consistent partial least squares method were used. The main result indicates that only the personalization strategy has a partial mediating effect. In conclusion, e-business capability alone is insufficient for achieving a superior innovation performance. This finding also helps consolidate the incipient study perspective that understands knowledge management not as an antecedent variable which becomes indispensable for e-business adoption, but as an organizational factor that intervenes a posteriori and which is focused on achieving an effective use of all the knowledge resulting from the digital operation of the business.
\end{abstract}

Keywords: information technology, e-business, knowledge management, innovation management, emerging economies

\section{INTRODUCTION}

The recent global information technology report has once again highlighted the close relationship between IT and innovation (World Economic Forum, 2016); the top- ranked countries on the Networked Readiness Index are precisely those that obtained the best results in innovation. This ranking, which measures the availability and use of IT, is spearheaded by developed countries, while emerging economies such as

\footnotetext{
*Corresponding author: jenrique.arias@udea.edu.co
}

DOI: doi.org/10.5937/sjm15-20446 
those from Latin American countries occupy intermediate positions, with Middle Eastern and African countries coming in last.

This issue has been broadly addressed in academic literature from the perspective of IT capabilities. There are several studies that have showed the positive effect of IT capabilities on innovation performance for three primary reasons: the improvement in knowledge flows, inter-organizational communication, and the direct support to specific stages in the innovation process (Kleis et al., 2012; Parida \& Örtqvist, 2015; Kroh et al., 2018). However, recently there has been more interest in examining the impact of e-business on innovation results aiming at analyzing more in detail the role of ITs which support the company's online transactions and the supply chain, under the assumption that this process creates interactions and provides information about customers, suppliers, and external allies who may be useful for the development of products (Van der Vorst et al., 2002; Zhu et al., 2015; Popa et al., 2018). These actors have traditionally been labeled as key sources of innovation (West \& Bogers, 2014; Bogers et al., 2018).

In particular, there are studies that have evidenced the positive effect of the use of ebusiness on innovation performance for three fundamental reasons: the efficient exchange of information between the company, the customers, and the supply chain; Big Data analytics; and the possibility of working without physical limitations (Soto-Acosta et al., 2016; Popa et al., 2018). Nevertheless, it has recently been suggested in the literature that obtaining improvements in organizational performance aspects such as innovation performance, based on ebusiness, is a process that takes time, and which requires the support from other organizational processes such as knowledge management. For example, to achieve an efficient use of Big Data on customers and suppliers, it is necessary to create an articulation with staff's tacit knowledge to produce new insights and specific applications of that knowledge. It is also necessary to have a codification system that enables the documentation of the new knowledge for future uses and subsequent learning processes (Sumbal et al., 2017). Therefore, this approach allows us to suppose there is a knowledge management mediating effect on the relationship between e-business and innovation performance.

This issue has gained a lot of relevance in the era of big data in which the great challenge of companies is no longer capturing information on customers and new technologies anymore, but creating and capturing value from those resources(Urbinati et al., 2019). For example, companies may have management information systems with detailed information on the business operation and consumers' consumption habits, but in many cases they are unable to use this information to increase customer satisfaction levels and generate new products (Dalla Pozza et al., 2018).

This emerging way of connecting knowledge management with e-business is quite novel and diametrically opposed to what has traditionally been proposed in the literature, given that the focus has been on studies that consider knowledge management an antecedent variable - which is indispensable for the adoption of ebusiness in companies that venture for the first time in this area (Lee \& Lin, 2005; YeeLoong Chong et al., 2014). This approach assumes that the technological platform that supports knowledge management processes 
can have a dual use and support e-business processes at the same time. However, there has been a shift in how this relationship is regarded: nowadays knowledge management has started to be considered an organizational factor that intervenes a posteriori, and which is in charge of achieving an effective use of all the knowledge derived from the digital operation of the business and from the information flows among the company, the customers, and the supply chain.

On the other hand, it has been suggested in the literature that e-business should be understood as an organizational skill and not just as a simple practice or management tool given its potential to alter the organization's resource base, particularly that of an intangible nature, such as knowledge, and in this way generate competitive advantages (Chi et al., 2010). Along these lines, ebusiness capability is the ability to connect, through information flows, the supply chain activities with the digital operation of the business, which comprises the processes of online purchases or e-procurement, online channel management, and online customer service (Zhu et al., 2015). Therefore, from this perspective, e-business is not simply an IT application that supports online transactions, but a strategic ability both to identify and take advantage of opportunities in the environment based on the knowledge obtained from customers, suppliers, and external partners. Nonetheless, given that this new approach is quite recent, the lack of studies that specifically analyze the relationship between e-business capability and innovation performance is evident.

Based on the above, the aim of this study is to analyze the mediating effect of knowledge management on the relationship between e-business capability and innovation performance, particularly the two traditional knowledge management strategies - personalization and codification - the former oriented toward the interaction among people for the exchange of tacit knowledge, and the latter focused on the documentation of people's knowledge and the exchange of explicit knowledge ( LópezNicolás \& Meroño-Cerdán, 2011; Braga et al., 2018; Buenechea-Elberdin et al., 2018). This mediation could be found given that the direct effects of e-business capability are insufficient to obtaining superior innovation performance, and a positive impact of ebusiness capability could only exist if there is an intermediation of the two knowledge management strategies. In the case of personalization, such intermediation would allow staff to interpret all the information about customers and suppliers that is derived from the e-business to create new insights and knowledge applications in the innovation process. In contrast, the mediating role of codification would be to document tacit knowledge, particularly staff's insights and experiences derived from their own interaction with customers, suppliers, and external partners in the context of the digital operation of the business, which could be potentially useful in the development of new and improved products and services.

The aim of this paper is to analyze the mediating effect of the knowledge management strategies on the relationship between e-business capabilities and innovation performance. The research model was tested with a sample of 102 firms belonging to IT intensive sectors, located in an emerging country that is a regional leader in terms of e-business adoption. The main contribution of this article is that it offers evidence to consolidate the incipient study 
perspective that understands knowledge management not as an antecedent variable which becomes indispensable for e-business adoption, but as an organizational factor that intervenes a posteriori and which is focused on achieving an effective use of all the knowledge resulting from the digital operation of the business.

\section{THEORETICAL FRAMEWORK AND HYPOTHESES}

\subsection{E-Business capability and innovation performance}

E-business capability is an organizational ability that enables the connection, through information flows, of supply chain activities with the digital operation of the business (Zhu et al., 2015; Popa et al., 2018). It allows the company to acquire, integrate, and reconfigure internal and external resources to create value (Grant, 1996), improve organizational performance based on IT, and connect the supply chain activities with the digital operation of the business through information flows (Zhao et al., 2008; Zhu et al., 2015). These capabilities create an environment conducive to the construction and maintenance of new sources of competitive advantage (Soto-Acosta et al., 2016). Since they provide more timely and accurate information for decision-making, they reduce costs (Gregory et al., 2017), improve the efficiency of customer service and the coordination and communication with business partners, among other possibilities (Lee \& Lin, 2005; CegarraNavarro et al., 2007; Lee et al., 2007). Ebusiness capability comprises three dimensions: online customer service capability, online purchasing capability, and online channel management capability (Johnson \& Whang, 2002; Zhu et al., 2015).

From a business perspective, innovation is viewed as new technological and business knowledge incorporated into new products or services that customers want (Afuah, 2003). Innovation performance refers to the concrete results of the innovation process, although there is a consensus around continuing to consider product innovation as the main success criterion in terms of innovation efforts (Alegre et al., 2006; Jiang \& Li, 2009). As a result, innovation performance is basically limited to the number of new products launched in the market, the number of these new products that has been successful, and the time that elapses between the development of a new product and its launch to the market (Sok \& O’Cass, 2011).

E-business is understood as a facilitator of innovation (Lee \& Lin, 2005; Koellinger, 2008; Popa et al., 2018) because it reconfigures business processes and supports the creation of networks in the economy and the dissemination of knowledge through the availability of new IT-based tools (Fahey et al., 2001; Moodley, 2003; Lin \& Hsia, 2011). In relation to the e-business customer service capability, "e-business is transforming the solutions available to customers in almost every industry, that is, the breadth of solutions and how the solutions are obtained and experienced" (Fahey et al., 2001).

The online customer service capability provides new ways to manage customer relationships and mechanisms to collect and exploit crucial external information to enhance innovation of new products (Popa et al., 2018). By allowing a better knowledge of customers' preferences and needs (Barua et al., 2004), it improves product experience, 
service performance, the solutions offered to customers, and product customization (Ash \& Burn, 2003), creating new opportunities to track and respond quickly to customer demand (Zhu et al., 2015). On the other hand, the online purchasing technological capability allows companies to create new competences through coordination and collaboration activities with suppliers (Ash \& Burn, 2003), improve the speed of logistics flow, and the detailed exchange of information.

\subsection{Mediating role of knowledge management strategies}

Knowledge management refers to the identification and use of collective knowledge in an organization to help it compete, which is achieved through processes of creation, storage, retrieval, transfer, and application of organizational knowledge (Alavi \& Leidner, 2001; Mitrović et al., 2018). These processes can hold a central role in the way that e-business capability potentiates innovation performance. The relationship with customers and suppliers established through e-business becomes a key channel for the acquisition of new market information, but for this information to be transformed into innovation, the company must have the corporate culture and technology systems that allow interpreting, distributing, and storing such information (Huber, 1991; Veselovská et al., 2018), which in turn may become technological knowledge to be applied in the development of new products and services.

Based on the work of Polanyi (1966), organizational knowledge is classified into two basic categories: explicit knowledge, which can be easily transferred through formal and systematic language; and tacit knowledge, which is not codified and is embedded in people through mental models, beliefs, perceptions, and abilities (Nonaka, 1994; Nonaka \& von Krogh, 2009). One of the central debates of the knowledge-based theory of the firm is how to reduce the costs of internal knowledge transfer successfully while preserving the quality and strategic value of such knowledge (Garcia-Muina et al., 2007; Buenechea-Elberdin et al., 2018). Company growth requires for its knowledge to be scalable and distributed to different organizational units, a task which is facilitated by the codification of tacit knowledge.

\subsubsection{Codification knowledge management strategies}

The codification knowledge management strategy refers to the capture of valuable knowledge in documents or systems, and the fostering of the link between people and documents (Venkitachalam \& Willmott, 2017). In the codification strategy, knowledge is extracted from the person who developed it, it becomes independent of that person, and is reused for various purposes (López-Nicolás \& Meroño-Cerdán, 2011; Buenechea-Elberdin et al., 2018). This requires the implementation of fast, reliable and high-quality information systems through the reuse of codified knowledge (Hansen et al., 1999).

In this context, codification plays an important role in how e-business capabilities influence the company's innovation performance. On the one hand, e-business capabilities are a facilitator to the codification strategies since they make it possible to capture, record, and store valuable knowledge and acquired 
experiences to make them available to the organization through documents and systems, with the aim that existing knowledge can be used and located more efficiently by anyone (Braga et al., 2018; Lee \& Choi, 2003). On the other hand, codification allows for reusing knowledge, saving time, reducing coordination and communication costs (Buenechea-Elberdin et al., 2018), and having more timely and accurate information for decision-making (Gregory et al., 2017) which facilitates the availability of explicit knowledge to produce creative ideas that may help to remain ahead of competitors, create product innovation, and increase performance (Choi et al., 2008).

Specifically, codification is a strategy that enables the information that is generated from the interaction with customers, suppliers and external partners through the company's virtual platforms to become explicit knowledge that may be used in multiple company areas. The fact that this explicit knowledge can be scalable and distributed can save time and reduce costs, promoting the success of innovation processes. Thus, the first hypothesis is proposed:

H1. The relationship between e-business capabilities and innovation performance is mediated by codification knowledge management strategies.

\subsubsection{Personalization knowledge management strategies}

The personalization knowledge management strategy refers to the fostering of the person-to-person connection and the timely association with experts (Venkitachalam \& Willmott, 2017; Buenechea-Elberdin et al., 2018), which favors the transfer of tacit knowledge among people. The personalization strategy focuses on dialog among individuals (López-Nicolás \& Meroño-Cerdán, 2011), which means providing analytically rigorous, creative advice on high-level strategic problems by way of channeling individual experience (Hansen et al., 1999).

Personalization plays a strategic role in how e-business capabilities drive innovation performance. On the one hand, through IT, ebusiness capabilities can help exchange knowledge that cannot be easily systematized (Pellegrini \& Martini, 2005). Personalization strategies can be supported by something as simple as e-mail or messaging tools, and by more advanced applications such as the organization's yellow pages, online forums, discussion groups, blogs, videoconferences, and even social media applications (Venkitachalam \& Willmott, 2017). On the other hand, personalization influences the generation of new and improved products, since much of the knowledge required for innovation is socially constructed and based on experience (Buenechea-Elberdin et al., 2018).

In short, the personalization strategy is what allows for interpreting customer information - relating to their needs and preferences - and information about suppliers - which is concerned with changes in the environment and technology - by means of person-to-person contact among staff and direct interaction with organizational experts. Said information comes from the digital operation of the business and aims at creating new insights with respect to current products, new product concepts, and devising new knowledge applications in the innovation process. Therefore, the second hypothesis is proposed: 
H2. The relationship between e-business capabilities and innovation performance is mediated by personalization knowledge management strategies.

\section{METHODOLOGY}

\subsection{Sample and data gathering}

The research model (Figure 1) was contrasted in a sample of manufacturing and service companies located in Colombia, an emerging country that occupies an intermediate position in the list of 139 countries recorded on the Networked Readiness Index (NRI) (World Economic Forum, 2016). The sample is made up of 102 Colombian manufacturing and service firms, both SMEs and large companies, which belong to IT-intensive sectors due to the weight of their electronic business activities which exceed 60\% (DANE, 2016) (Table 1). The data was collected during October of
2015 through a questionnaire sent by electronic mail to the management or strategic-level staff from different functional areas of each one of the surveyed companies. The sample size permits to guarantee a satisfactory power test above $80 \%$ (Cohen, 1988).

\subsection{Measurement scales}

The measurement scales considered in the model are presented in Table 2. For the ebusiness capability construct, 10 items were considered based on the scale proposed by Zhu et al. (2015). In turn, the knowledge management strategies were divided into two constructs, codification and personalization strategies, comprising 4 items each, in accordance with the scale proposed by Choi and Lee (2003) and adapted by LópezNicolás and Meroño-Cerdán (2011). For these two constructs, a 5-point Likert scale was used (1: totally disagree, 5: totally agree). For the IP construct, the product-

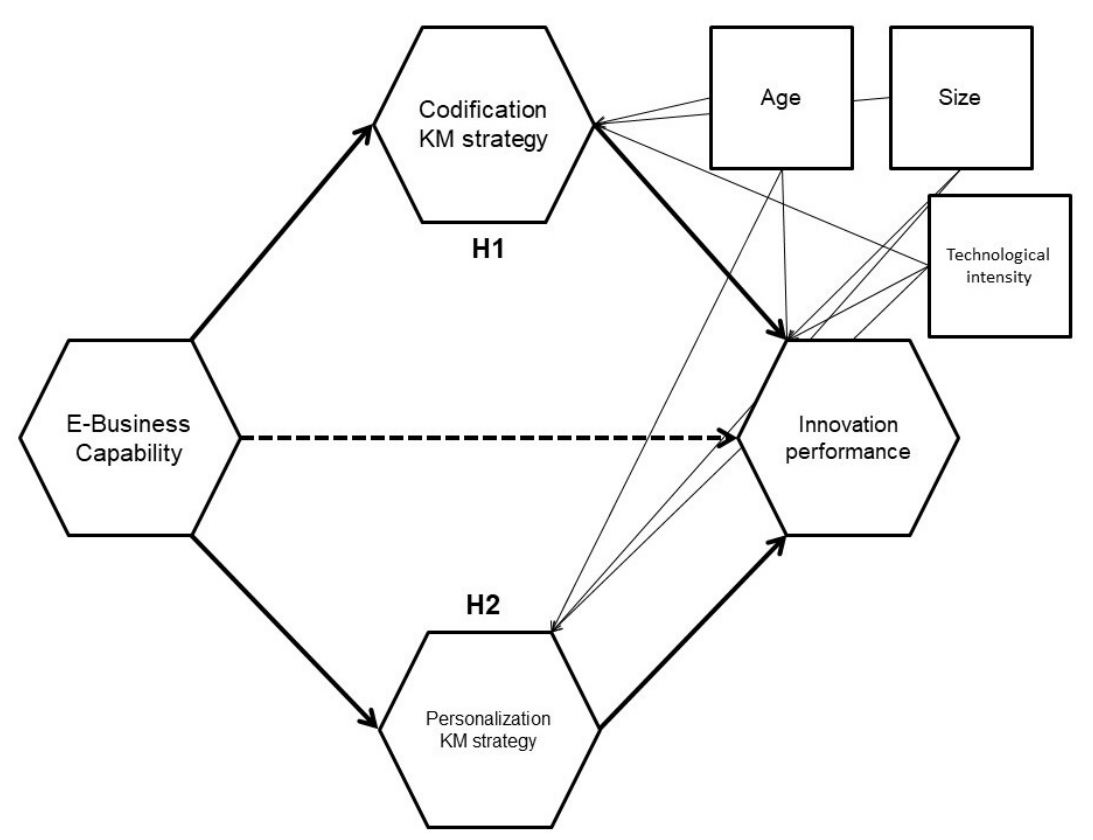

Figure 1. Research model 
Table 1. Characteristics of the companies in the sample

\begin{tabular}{|c|c|c|}
\hline & Frequency & Percentage \\
\hline \multicolumn{3}{|l|}{ Sector } \\
\hline Business management activities; management consulting activities & 23 & $22.55 \%$ \\
\hline Information and communications & 16 & $15.69 \%$ \\
\hline Education & 12 & $11.76 \%$ \\
\hline Clothing manufacturing & 8 & $7.84 \%$ \\
\hline Human health attention and social assistance activities & 6 & $5.88 \%$ \\
\hline Accommodation and food services & 6 & $5.88 \%$ \\
\hline Wholesaling and retailing; motor vehicle and motorcycle repair & 5 & $4.90 \%$ \\
\hline Manufacturing of metal products, except machinery and equipment & 4 & $3.92 \%$ \\
\hline Manufacturing of chemical substances and products & 4 & $3.92 \%$ \\
\hline Other manufacturing activities & 4 & $3.92 \%$ \\
\hline Transport and storage & 3 & $2.94 \%$ \\
\hline Manufacturing of electric devices and equipment & 2 & $1.96 \%$ \\
\hline $\begin{array}{l}\text { Manufacturing of dental and medical instruments, devices and materials (including } \\
\text { furniture) }\end{array}$ & 2 & $1.96 \%$ \\
\hline Manufacturing of games, toys and puzzles & 1 & $0.98 \%$ \\
\hline Financial and insurance activities & 1 & $0.98 \%$ \\
\hline Real estate activities & 1 & $0.98 \%$ \\
\hline Water distribution; waste water evacuation and treatment, waste management & 1 & $0.98 \%$ \\
\hline Other service activities & 3 & $2.94 \%$ \\
\hline \multicolumn{3}{|l|}{ Size by number of employees } \\
\hline Large companies & 25 & $24.51 \%$ \\
\hline SMEs & 77 & $75.49 \%$ \\
\hline \multicolumn{3}{|l|}{ Functional area of the respondent } \\
\hline Presidency or General Management & 51 & $50.00 \%$ \\
\hline IT & 14 & $13.73 \%$ \\
\hline Marketing & 12 & $11.76 \%$ \\
\hline Others & 8 & $7.84 \%$ \\
\hline Research and Development & 6 & $5.88 \%$ \\
\hline Finances & 5 & $4.90 \%$ \\
\hline Production & 3 & $2.94 \%$ \\
\hline Human Resources & 3 & $2.94 \%$ \\
\hline
\end{tabular}

centered performance scale proposed by Sok and O'Cass (2011) was employed and a 5point Likert scale was used (1: Very inferior to competitors in the last 3 years, 5: Very superior to competitors in the last 3 years).

\subsection{Reliability and validity}

In the case of individual reliability (Table $3)$, we verified that all items had a factor loading equal or above 0.7 , with the exception of e-business capability, whose scale is recent and is still being tested in subsequent studies and in different contexts from the one in which it was initially developed. In this case, a factor loading above 0.6 is acceptable (Hair Jr et al., 2017).
Also, we verified that all the constructs presented a Cronbach's alpha (CA) and a Dillon-Goldstein's or composite reliability index (pC) above 0.7, and a variance extracted index (VEI) greater than 0.5. Additionally, we calculated the new construct reliability indicator, the DijkstraHenseler (pA), and confirmed that it was above 0.7 (Dijkstra \& Henseler, 2015). Adanco was the software used for the statistical analysis.

\subsection{Discriminant validity}

To establish discriminant validity we first verified meeting the Fornell-Larcker criterion; in this case (see Table 4), the 
Table 2. Measurement scales

\begin{tabular}{|c|c|c|}
\hline Construct /Sources & Code & Item \\
\hline \multirow{10}{*}{$\begin{array}{l}\text { E-business } \\
\text { capabilities (EBC) }\end{array}$} & $\mathrm{EBC} 1$ & $\begin{array}{l}\text { The online procurement operations process has been restructured to facilitate } \\
\text { negotiations and transactions. }\end{array}$ \\
\hline & EBC2 & Order catalogs are shared online with suppliers to facilitate purchase. \\
\hline & EBC3 & $\begin{array}{l}\text { Raw materials demand information is shared online with suppliers to } \\
\text { facilitate procurement of supplies. }\end{array}$ \\
\hline & $\mathrm{EBC} 4$ & The company provides online customer service on the website. \\
\hline & EBC5 & $\begin{array}{l}\text { The company provides value-added services on the website for potential } \\
\text { customers (e.g., resolves queries on the characteristics and quality of products } \\
\text { and services) }\end{array}$ \\
\hline & EBC6 & $\begin{array}{l}\text { The company provides online customer service to address customer feedback } \\
\text { and suggestions. }\end{array}$ \\
\hline & EBC7 & $\begin{array}{l}\text { The online transaction process has been restructured to support ordering } \\
\text { management. }\end{array}$ \\
\hline & EBC8 & $\begin{array}{l}\text { Marketing policies are shared online with retailers to facilitate the promotion } \\
\text { of products and services. }\end{array}$ \\
\hline & EBC9 & $\begin{array}{l}\text { Product and service catalogs are shared online with retailers to facilitate } \\
\text { managing products and services. }\end{array}$ \\
\hline & $\mathrm{EBC} 10$ & $\begin{array}{l}\text { Production activities schedules are shared online with retailers to facilitate } \\
\text { meeting with delivery dates. }\end{array}$ \\
\hline \multirow{4}{*}{$\begin{array}{l}\text { Codification } \\
\text { knowledge } \\
\text { management strategy } \\
\text { (COD) }\end{array}$} & COD1 & Knowledge is well codified and documented in the company. \\
\hline & COD2 & $\begin{array}{l}\text { Knowledge can be acquired easily by any employee of the company through } \\
\text { documents or manuals. }\end{array}$ \\
\hline & COD3 & Results of projects and meetings should be documented in the company. \\
\hline & COD4 & $\begin{array}{l}\text { Knowledge is shared through codified forms like manuals or documents in } \\
\text { the company }\end{array}$ \\
\hline \multirow{4}{*}{$\begin{array}{l}\text { Personalization } \\
\text { knowledge } \\
\text { management strategy } \\
\text { (PERS) }\end{array}$} & PERS 1 & $\begin{array}{l}\text { Knowledge can be easily acquired from experts and co-workers in the } \\
\text { company. }\end{array}$ \\
\hline & PERS2 & $\begin{array}{l}\text { It is recurrent and easy to get face-to-face advice from experts in the } \\
\text { company. }\end{array}$ \\
\hline & PERS3 & $\begin{array}{l}\text { Informal dialogs and meetings are used for knowledge sharing in the } \\
\text { company }\end{array}$ \\
\hline & PERS4 & Knowledge is transferred by one-to-one mentoring in the company. \\
\hline \multirow{3}{*}{$\begin{array}{l}\text { Innovation } \\
\text { performance (IP) }\end{array}$} & IP1 & The number of new or improved products launched in the market. \\
\hline & IP2 & The number of successful products launched in the market. \\
\hline & IP3 & $\begin{array}{l}\text { The time that elapses between the development of a new product and its } \\
\text { launch in the market. }\end{array}$ \\
\hline
\end{tabular}

variance extracted index is greater than the correlations of the squared constructs (Fornell \& Larcker, 1981). Secondly, we confirmed that all Heterotrait-Monotrait (HTMT) values were under the threshold of 0.85 or 0.90 (Henseler et al., 2015).

\subsection{Mediating effect test}

The study adopted the procedure used by Zhao et al., (2010), who propose confirming the statistical significance of indirect effects (a x b) through the bootstrap-percentile test (Preacher \& Hayes, 2008). To do this, structural equations by the method of consistent partial least squares (PLSc) were used in order to obtain the confidence intervals at $95 \%$ and the $t$ values of the coefficients of the different trajectories, from a resampling of 4999 subsamples (Henseler et al., 2009).

Table 5 shows that the trajectory of the indirect effect between e-business capability and codification is positive and significant 
Table 3. Reliability and convergent validity

\begin{tabular}{|c|c|c|c|c|c|c|}
\hline Constructs & Standardized loading & t value & CA & (pC) & VEI & $\mathbf{p A}$ \\
\hline E-business capability & & & 0.91 & 0.92 & 0.53 & 0.92 \\
\hline $\mathrm{EBC} 1$ & $0.65 *$ & 7.03 & & & & \\
\hline $\mathrm{EBC} 2$ & $0.61 *$ & 5.79 & & & & \\
\hline $\mathrm{EBC} 3$ & $0.70 *$ & 7.81 & & & & \\
\hline EBC4 & $0.77 *$ & 16.32 & & & & \\
\hline EBC5 & $0.77 *$ & 16.89 & & & & \\
\hline EBC6 & $0.78^{*}$ & 17.98 & & & & \\
\hline $\mathrm{EBC7}$ & $0.67 *$ & 8.66 & & & & \\
\hline EBC8 & $0.80 *$ & 15.52 & & & & \\
\hline EBC9 & $0.79 *$ & 19.01 & & & & \\
\hline EBC10 & $0.74 *$ & 10.67 & & & & \\
\hline Codification & & & 0.87 & 0.91 & 0.72 & 0.89 \\
\hline COD1 & $0.86^{*}$ & 25.07 & & & & \\
\hline COD2 & $0.90 *$ & 36.52 & & & & \\
\hline COD3 & $0.71 *$ & 8.28 & & & & \\
\hline COD4 & $0.91 *$ & 43.46 & & & & \\
\hline Personalization & & & 0.91 & 0.94 & 0.79 & 0.92 \\
\hline PERS1 & $0.89 *$ & 26.78 & & & & \\
\hline PERS2 & $0.87 *$ & 20.47 & & & & \\
\hline PERS3 & $0.90 *$ & 31.68 & & & & \\
\hline PERS4 & $0.90 *$ & 40.81 & & & & \\
\hline Innovation performance & & & 0.89 & 0.93 & 0.81 & 0.89 \\
\hline IP1 & $0.92 *$ & 46.99 & & & & \\
\hline IP2 & $0.89 *$ & 26.13 & & & & \\
\hline IP3 & $0.89 *$ & 26.27 & & & & \\
\hline
\end{tabular}

Table 4. Discriminant validity

\begin{tabular}{lllllllll}
\hline Construct & \multicolumn{1}{c}{ Fornell-Larcker } & \multicolumn{5}{c}{ HTMT } \\
\cline { 2 - 9 } & 1 & 2 & 3 & 4 & 1 & 2 & 3 & 4 \\
\hline 1. E-business capability & $\mathbf{0 . 5 3}$ & & & & & & & \\
2. Codification & 0.26 & $\mathbf{0 . 7 2}$ & & & 0.53 & & \\
3. Personalization & 0.10 & 0.43 & $\mathbf{0 . 7 9}$ & & 0.31 & 0.74 & \\
4. Innovation performance & 0.16 & 0.24 & 0.25 & $\mathbf{0 . 8 1}$ & 0.40 & 0.56 & 0.55 \\
\hline Notes: The VEI appear in bold type on the diagonal; the squared correlations appear below the VEI
\end{tabular}

$(\beta=0.54 ; \mathrm{t}$ value $=5.95)$, but the trajectory between codification and innovation performance is not significant $(\beta=0.22 ; \mathrm{t}$ value $=1.56$ ), which means $\mathrm{H} 1$ is not supported. In turn, the trajectories between ebusiness capability and personalization $(\beta=0.38 ; \quad \mathrm{t} \quad$ value $=3.81)$ and between personalization and innovation performance $(\beta=0.34 ; \mathrm{t}$ value $=3.19)$ are significant and have a positive sign, which would in principle lead to accepting H2. Mediation is only indirect given the inexistence of direct effects since the trajectory between e- business capability and innovation performance is not significant $(\beta=0.15 ; \mathrm{t}$ value $=1.28$ ) (Zhao et al., 2010). Furthermore, in the hypothesis model the influence of some control variables is significant, particularly, size and technology intensity.

However, when confirming the existence of mediation in the case of $\mathrm{H} 2$, the bootstrappercentile analysis indicates that zero (0) is not contained in the confidence interval at $95 \%$ of the indirect effect (Table 6). Therefore, H2 is conclusively accepted. 
Table 5. Structural equations results

\begin{tabular}{lccc}
\hline Trajectories & Coefficient & t value & Confidence interval at 95\% \\
\hline Direct effects & & & \\
\hline E-business capability -> Innovation performance & 0.15 & 1.28 & {$[-0.07 ; 0.38]$} \\
E-business capability -> Codification & $0.54^{* * *}$ & 5.95 & {$[0.37 ; 0.73]$} \\
E-business capability -> Personalization & $0.38^{* * *}$ & 3.81 & {$[0.17 ; 0.57]$} \\
Codification -> Innovation performance & 0.22 & 1.56 & {$[-0.06 ; 0.51]$} \\
Personalization -> Innovation performance & $0.34^{* *}$ & 3.19 & {$[0.12 ; 0.55]$} \\
\hline Control variables & & & \\
\hline Age -> Innovation performance & -0.02 & -0.18 & {$[-0.25 ; 0.21]$} \\
Age -> Codification & 0.11 & 0.90 & {$[-0.14 ; 0.35]$} \\
Age -> Personalization & -0.04 & -0.30 & {$[-0.30 ; 0.20]$} \\
Size -> Innovation performance & 0.13 & 0.98 & {$[-0.12 ; 0.38]$} \\
Size -> Codification & $-0.23^{*}$ & -2.18 & {$[-0.43 ;-0.02]$} \\
Size -> Personalization & -0.20 & -1.49 & {$[-0.44 ; 0.07]$} \\
Technology intensity -> Innovation performance & -0.12 & -1.30 & {$[-0.28 ; 0.06]$} \\
Technology intensity -> Codification & $0.30^{* * *}$ & 3.70 & {$[0.13 ; 0.44]$} \\
Technology intensity -> Personalization & $0.21^{*}$ & 2.15 & {$[0.01 ; 0.38]$} \\
\hline
\end{tabular}

Table 6. Indirect effect and VAF

\begin{tabular}{|c|c|c|c|c|}
\hline Trajectory & $\begin{array}{c}\text { Direct } \\
\text { effect }\end{array}$ & $\begin{array}{l}\text { Mediated } \\
\text { effect }\end{array}$ & $\begin{array}{l}\text { Confidence } \\
\text { intervals }\end{array}$ & VAF \\
\hline $\begin{array}{l}\text { E-business capability }->\text { Personalization }->\text { Innovation } \\
\text { performance }\end{array}$ & 0.15 & 0.13 & {$[0.03 ; 0.26]$} & 0.47 \\
\hline
\end{tabular}

Added to the above, the variance-accountedfor (VAF) test was performed, which allows to establish the magnitude of the indirect effect with regard to the total, which is $47 \%$ in this case, indicating that mediation is partial (Hair Jr et al., 2017).

\section{DISCUSSION}

The results show that personalization is the key strategy to use the knowledge derived from e-business since it fosters faceto-face interaction among employees, which allows interpreting the information to the point of converting such knowledge into a concrete input for the development of new and improved products. In contrast, codification does not play a mediating role, probably because knowledge resulting from the digital operation of the business is mainly explicit and thus deepening into the codification of this knowledge may be redundant and not very beneficial for improving innovation performance. Conversely, there is a clear need to favor face-to-face discussion spaces so that people can generate new innovation ideas from the information yielded by e-business.

\section{CONCLUSIONS}

This work contributes to the literature in diverse ways. Firstly, it provides evidence demonstrating that e-business must be understood not simply as a management practice or tool as has been mainly regarded in the literature, but as an organizational ability that completely alters the resource base of the organization, particularly that of an intangible nature such as knowledge, and permits to reach a superior IP. In this sense, this work is pioneering in connecting e- 
business capability and innovation and thus offers a novel form of understanding this relationship. Under this new perspective, ebusiness is not simply an application of IT that supports network transactions and provides information to feed the innovation process, but it is mainly a strategic ability enabling the detection and exploitation of opportunities in the environment from the knowledge obtained from customers, suppliers and external allies.

Secondly, this study evidences that the relationship between e-business capability and innovation performance is mediated only partially by the personalization strategy, which suggests that the influence of ebusiness capability alone is not sufficient to achieve a superior IP, contrary to what has been suggested by previous studies (SotoAcosta et al., 2016). This contribution is quite significant since it evidences the organizational limitations to innovate from the information on customers, suppliers and external allies, derived from e-business. There is a necessity to generate interaction between such information and the tacit knowledge of people, who are ultimately the ones with the ability to interpret it, and generate new insights and applications in the innovation process. Furthermore, this finding helps consolidate the incipient study perspective that understands knowledge management strategies not as an antecedent variable that becomes indispensable for the adoption of e-business in firms entering this field for the first time, but as an organizational factor that intervenes a posteriori, and which is in charge of achieving an effective use of all the knowledge derived from the digital operation of the business.

Thirdly, in the case of codification, there is no mediating effect, which indicates that a strategy oriented toward technology with the aim of generating and combining more explicit knowledge becomes irrelevant and redundant with the e-business capability information outputs. In this case, interpretation is what is required to generate innovation. This result contrasts with previous studies that emphasize the importance of codification in innovation processes in emerging countries (LópezNicolás \& Meroño-Cerdán, 2011; Buenechea-Elberdin et al., 2018). Thus, we are forced to reframe this type of studies that usually analyze the relationship between knowledge management strategies and innovation performance in a rather generic way, without detailing the knowledge sources and inputs in which the transforming actions of the knowledge management strategies lie. In this case, the knowledge management strategies are at the service of an organizational ability such as e-business capability, with a clear external orientation which generates high volumes of specific information on customers, suppliers and external allies, which are the inputs of the knowledge management strategies. Under this particular scenario, codification ceases to be relevant and behaves as a different form from what has been described in the generic scenarios presented in previous studies.

Hence, it may be more sensible to have a system that allows codifying the new knowledge that individuals generate from combining their tacit knowledge with the information derived from the digital operation of the business for future use and subsequent learning processes. This should be done instead of deploying codification strategies oriented to document employees' insights and experiences from their interaction with customers, suppliers and external allies in the e-business context that 
could be potentially useful in the development of new or improved products and services. In other words, concerning ebusiness capability, it would be more sensible to first deploy personalization and later codification, that is, not simultaneously as widely proposed in the literature (Storey \& Kahn, 2010), but sequentially.

Therefore this paper offers a new way of understanding the role of knowledge management strategies in organizations, since in the literature there is a prevailing study approach that places both knowledge management strategies in a generic scenario in which they function as exogenous and independent variables (Storey \& Kahn, 2010; López-Nicolás \& Meroño-Cerdán, 2011; Buenechea-Elberdin et al., 2018). Under that assumption, such study approach advances in the identification of mediating variables in the relationship between knowledge management strategies and diverse organizational constructs (Liao, 2011; Erwee et al., 2012; Imran et al., 2016; Popa et al., 2018). However, based on the findings of the present paper, knowledge management strategies should be considered as an intermediate endogenous variable, serving as a bridge to maximize the effective use of great amounts of tacit and explicit knowledge generated by diverse organizational factors with a strong external orientation such as e-business capability.

This new approach is a significant contribution that opens the possibility of addressing knowledge management strategies in a more contingent manner, not on the basis of the traditional criteria associated with the environment and IT internal resources (Imran et al., 2016), but based on the nature and particularities of the tacit or explicit knowledge input previously yielded by another organizational actor. For instance, in the case of constructs such as knowledge co-creation with customers and other stakeholders that usually generate more tacit knowledge due to their conversational nature (Kazadi et al., 2016), the codification strategy could play a key mediating role in the relationship between that construct and IP. This is due to the necessity to document the insights derived from this collaborative work, contrary to what has occurred in the present paper with a more technologyoriented construct such as e-business capability.

As for practical implications, the existence of a partial mediation of the personalization strategy supposes that a firm must connect e-business with practices that allow to have dialog and face-to-face or virtual interpersonal interaction among employees. These could then interpret, analyze and discuss the information derived from the digital operation of the business with the purpose of ideating new knowledge applications that aim at the development of new and improved products and services. The mediation of the personalization strategy supposes the implementation of practice communities, discussion groups, informal dialog, mentoring, conferences, among other strategies, in which discussion can be generated around a report resulting from ebusiness that synthetizes market trends, consumer behavior changes, and technological changes reported by suppliers and external allies, which serves as the basis to improve innovation results.

Regarding the study limitations, it must be emphasized that the results are contingent to firms located in an emerging economy which, although it has been consolidating itself as leader in South America in terms of e-business adoption, it just occupies an intermediate position on the Networked 
Readiness Index, particularly in what regards internet use for Business-to-Consumer (World Economic Forum, 2016). Therefore, there would be limitations to generalize these results to other types of contexts where firms have reached a higher maturity degree in terms of e-business adoption, where IT are so intensively used that have even become an industry standard that provides little differentiation and marginally impacts on diverse organizational performance aspects (Chae et al., 2014).

Another limitation of the study has to do with another particularity of the context: the inexistence of the mediating effect of codification in firms located in a technology follower country. This aspect has a reasonably high score on the power distance dimension of the country's culture (Hofstede, 1983). Several previous studies have demonstrated that this strategy is key to innovation but it has a lesser presence in comparison with firms in developed countries, technology leaders, which score low on said dimension of the country's culture (López-Nicolás \& Meroño-Cerdán, 2011; Buenechea-Elberdin et al., 2018). Thus, there would be limitations to generalize the results of this study to firms located in that other context where the codification strategy is more deeply rooted in the organizational context.

Future studies should replicate this model in firms located in countries that have reached greater maturity in terms of ebusiness adoption and where the codification strategy has more presence, with the aim of elucidating to what extent the present findings are conditioned by the particularities of the context. On the other hand, it would be worth considering the mediating role of the knowledge management strategies in the proven relationship between several organizational factors and innovation performance. This generates a lot of explicit knowledge output such as quality management (Terziovski \& Guerrero, 2014) and IT capabilities (Chen et al., 2015), or a lot of tacit knowledge such as open innovation (Bianchi et al., 2016), being part of an industry cluster (Lai et al., 2014), human management practices (Chen \& Huang, 2009), and strategic market orientation (Duan \& Zhang, 2010), among others. In this way, the study focus proposed in this paper would be developed considering knowledge management strategies as an intermediate contingent variable which maximizes the effective use of the innovation processes knowledge previously yielded by other organizational processes in the form of output, depending on the tacit or explicit nature of such knowledge.

Acknowledgement: This work was supported by Universidad de Antioquia under project number 2019-25750.

\section{References}

Afuah, A. (2003). Innovation management: strategies, implementation and profits. In Oxford University Press.

Alavi, M., \& Leidner, D.E. (2001). Knowledge management and knowledge management systems: Conceptual foundations and research issues. MIS Quarterly, 25 (1), 107-136.

Alegre, J., Lapiedra, R., \& Chiva, R. (2006). A measurement scale for product innovation performance. European Journal of Innovation Management, 9 (4), 333-346.

Ash, C.G., \& Burn, J.M. (2003). A strategic framework for the management of ERP enabled e-business change. European 


\title{
МОГУЋНОСТИ Е-ПОСЛОВАЊА И ИНОВАЦИОНЕ ПЕРФОРМАНСЕ: ПОСРЕДНИЧКИ ЕФЕКАТ СТРАТЕГИЈА УПРАВЉАЫА ЗНАЫЕМ
}

\author{
Jose Arias, Esteban López, Andrea Echeverri
}

\section{Извод}

Циљ овог рада је да се анализира посреднички ефекат стратегија управљања знањем на однос између могућности е-пословања и иновационих перформанси. Модел истраживања тестиран је на узорку од 102 предузећа, која припадају интензивном ИТ сектору, смештених у земљи у успону која је регионални лидер у погледу усвајања е-пословања. Коришћен је метод структурних једначина које се састоје од парцијалних најмањих квадрата. Главни резултат указује на то да само стратегија персонализације има делимичан посреднички ефекат. Закључно, само способност е-пословања није довољна за постизање врхунских иновационих перформанси. Ово откриће такође помаже консолидацији перспективе почетног проучавања која управљање знањем не схвата као променљиву претходника која постаје неопходна за усвајање е-пословања, већ као организациони фактор који интервенише а постериори и који је усмерен на постизање ефикасне употребе свих знања која произилазе из дигиталног пословања предузећа.

Кључне речи: информациона технологија, е-пословање, управљање знањем, управљање иновацијама, економије у развоју

Journal of Operational Research, 146 (2), knowledge-intensive business services. 374-387.

Journal of the Knowledge Economy, 9 (2),

Barua, A., Konana, P., Whinston, A.B., \& 359-377.

Yin, F. (2004). An empirical investigation of net-enabled business value. MIS Quarterly, 28 (4), 585-620.

Bianchi, M., Croce, A., Dell'Era, C., Di Benedetto, C.A., \& Frattini, F. (2016). Organizing for Inbound Open Innovation: How External Consultants and a Dedicated R\&D Unit Influence Product Innovation Performance. Journal of Product Innovation Management, 33 (4), 492-510.

Buenechea-Elberdin, M., Sáenz, J., \& Kianto, A. (2018). Knowledge management strategies, intellectual capital, and innovation performance: a comparison between highand low-tech firms. Journal of Knowledge Management, 22 (8), 1757-1781.

Cegarra-Navarro, J.G., Jiménez, D.J., \& Martínez-Conesa, E.Á. (2007). Implementing e-business through organizational learning: An empirical

Bogers, M., Chesbrough, H., \& Moedas, C. (2018). Open innovation: Research, practices, and policies. California Management Review, 60 (2), 5-16. investigation in SMEs. International Journal of Information Management, 27 (3), 173186.

Braga, A., Marques, C.S., \& Serrasqueiro,

Chae, H.-C., Koh, C.E., \& Prybutok, V.R. (2014). Information Technology Capability Z. (2018). Internationalisation strategy of and Firm Performance: Contradictory 
Findings and Their Possible Causes. MIS Quaterly, 38 (1), 305-326.

Chen, C.-J., \& Huang, J.-W. (2009). Strategic human resource practices and innovation performance - The mediating role of knowledge management capacity. Journal of Business Research, 62 (1), 104114.

Chen, Y., Wang, Y., Nevo, S., BenitezAmado, J., \& Kou, G. (2015). IT capabilities and product innovation performance: The roles of corporate entrepreneurship and competitive intensity. Information \& Management, 52 (6), 643-657.

Chi, M., Zhao, J., Lu, Z., \& Liu, Z. (2010). Analysis of E-business capabilities and performance: From e-SCM process view. 3rd International Conference on Computer Science and Information Technology, Chengdu, 1, 18-22.

Choi, B., \& Lee, H. (2003). An empirical investigation of KM styles and their effect on corporate performance. Information \& Management, 40 (5), 403-417.

Choi, B., Poon, S. K., \& Davis, J.G. (2008). Effects of knowledge management strategy on organizational performance: A complementarity theory-based approach. Omega, 36 (2), 235-251.

Cohen, J. (1988). Statistical Power Analysis for the Behavioural Science (2nd Edition). In Statistical Power Anlysis for the Behavioural Science (2nd Edition). Lawrence Erlbaum Associates, USA.

Dalla Pozza, I., Goetz, O., \& Sahut, J.M. (2018). Implementation effects in the relationship between CRM and its performance. Journal of Business Research, 89, 391-403.

DANE. (2016). Indicators of information and communication technology use in colombian companies. Retrieved from http://www.dane.gov.co/files/investigaciones /boletines/tic/bol_empresas_2014def.pdf.

Dijkstra, T.K., \& Henseler, J. (2015). Consistent Partial Least Squares Path Modeling. MIS Quarterly, 39 (2), 297-316.

Duan, Y., \& Zhang, J. (2010). The impact of different types of market orientation on product innovation performance: Evidence from Chinese manufacturers. Management Decision, 48 (6), 849-867.

Erwee, R., Skadiang, B., \& Roxas, B. (2012). Knowledge management culture, strategy and process in Malaysian firms. Knowledge Management Research \& Practice, 10 (1), 89-98.

Fahey, L., Srivastava, R., Sharon, J.S., \& Smith, D.E. (2001). Linking e-business and operating processes: The role of knowledge management. IBM Systems Journal, 40 (4), 889-907.

Fornell, C., \& Larcker, D.F. (1981). Evaluating Structural Equation Models with Unobservable Variables and Measurement Error. Journal of Marketing Research, 18 (1), 39-50.

Garcia-Muina, F.E., Pelechano-Barahona, E., \& Navas-Lopez, J.E. (2007). Knowledge Codification and Technological Innovation Success: Empirical Evidence from Spanish Biotech Companies. PICMET '07 - 2007 Portland International Conference on Management of Engineering \& Technology, Portland, OR, 1062-1071.

Grant, R.M. (1996). Prospering in Dynamically-Competitive Environments: Organizational Capability as Knowledge Integration. Organization Science, 7 (4), 375-387.

Gregory, G.D., Ngo, L.V., \& Karavdic, M. (2017). Developing e-commerce marketing capabilities and efficiencies for enhanced performance in business-to-business export ventures. Industrial Marketing Management, $78,146-157$. 
Hair Jr, J.F., Hult, G.T.M., Ringle, C., \& Sarstedt, M. (2017). A primer on partial least squares structural equation modeling (PLSSEM). Los Angeles: Sage Publications.

Hansen, M.T., Nohria, N., \& Tierney, T. (1999). What's your strategy for managing knowledge? Harvard Business Review, 77 (2), 106-116.

Henseler, J., Ringle, C.M., \& Sarstedt, M. (2015). A new criterion for assessing discriminant validity in variance-based structural equation modeling. Journal of the Academy of Marketing Science, 43 (1), 115135.

Henseler, J., Ringle, C.M., \& Sinkovics, R.R. (2009). The use of partial least squares path modeling in international marketing. In R. R. Sinkovics \& G. Pervez (Eds.), New Challenges to International Marketing, 20, 277-319.

Hofstede, G. (1983). National Cultures in Four Dimensions: A Research-Based Theory of Cultural Differences among Nations. International Studies of Management \& Organization, 13 (1-2), 46-74.

Huber, G.P. (1991). Organizational Learning: The Contributing Processes and the Literatures. Organization Science, 2 (1), 88-115.

Imran, M.K., Rehman, C.A., Aslam, U., Bilal, A R., \& Aslam, U. (2016). What's organization knowledge management strategy for successful change implementation? Journal of Organizational Change Management, 29 (7), 1097-1117.

Jiang, X., \& Li, Y. (2009). An empirical investigation of knowledge management and innovative performance: The case of alliances. Research Policy, 38 (2), 358-368.

Johnson, M.E., \& Whang, S. (2002). Ebusiness and supply chain management: an overview and framework. Production and Operations Management, 11 (4), 413-423.
Kazadi, K., Lievens, A., \& Mahr, D. (2016). Stakeholder co-creation during the innovation process: Identifying capabilities for knowledge creation among multiple stakeholders. Journal of Business Research, 69 (2), 525-540.

Kleis, L., Chwelos, P., Ramirez, R.V., \& Cockburn, I. (2012). Information Technology and Intangible Output: The Impact of IT Investment on Innovation Productivity. Information Systems Research, 23 (1), 42-59.

Koellinger, P. (2008). The relationship between technology, innovation, and firm performance-Empirical evidence from ebusiness in Europe. Research Policy, 37 (8), 1317-1328.

Kroh, J., Luetjen, H., Globocnik, D., \& Schultz, C. (2018). Use and Efficacy of Information Technology in Innovation Processes: The Specific Role of Servitization. Journal of Product Innovation Management, 35 (5), 720-741.

Lai, Y.-L., Hsu, M.-S., Lin, F.-J., Chen, Y.-M., \& Lin, Y.-H. (2014). The effects of industry cluster knowledge management on innovation performance. Journal of Business Research, 67 (5), 734-739.

Lee, H., \& Choi, B. (2003). Knowledge management enablers, processes, and organizational performance: An integrative view and empirical examination. Journal of Management Information Systems, 20 (1), 179-228.

Lee, C., Lee, G., \& Lin, H. (2007). The role of organizational capabilities in successful e-business implementation. Business Process Management Journal, 13 (5), 677-693.

Lee, G., \& Lin, H. (2005). Impact of organizational learning and knowledge management factors on e-business adoption. Management Decision, 43 (2), 171-188. 
Liao, Y. (2011). The effect of human resource management control systems on the relationship between knowledge management strategy and firm performance. International Journal of Manpower, 32 (5/6), 494-511.

Yee-Loong Chong, A., Ooi, K.-B., Bao, H., \& Lin, B. (2014). Can e-business adoption be influenced by knowledge management? An empirical analysis of Malaysian SMEs. Journal of Knowledge Management, 18 (1), 121-136.

Lin, L.-M., \& Hsia, T.-L. (2011). Core capabilities for practitioners in achieving ebusiness innovation. Computers in Human Behavior, 27(5), 1884-1891.

López-Nicolás, C., \& Meroño-Cerdán, Á. (2011). Strategic knowledge management, innovation and performance. International Journal of Information Management, 31 (6), 502-509.

Mitrović, Z., Obradović, V., \& Suknović, M. (2018). Knowledge management in the public sector: The case of Serbian local government. Serbian Journal of Management, 13 (2), 293-309.

Moodley, S. (2003). The challenge of ebusiness for the South African apparel sector. Technovation, 23 (7), 557-570.

Nonaka, I. (1994). A Dynamic Theory of Organizational Knowledge Creation. Organization Science, 5 (1), 14-37.

Nonaka, I., \& von Krogh, G. (2009). Perspective-Tacit Knowledge and Knowledge Conversion: Controversy and Advancement in Organizational Knowledge Creation Theory. Organization Science, 20 (3), 635-652.

Parida, V., \& Örtqvist, D. (2015). Interactive Effects of Network Capability, ICT Capability, and Financial Slack on Technology-Based Small Firm Innovation Performance. Journal of Small Business
Management, 53 (S1), 278-298.

Pellegrini, L., \& Martini, A. (2005). Barriers and levers towards knowledge management configurations: A case studybased approach. Journal of Manufacturing Technology Management, 16 (6), 670-681.

Polanyi, M. (1966). The Tacit Dimension. Anchor Books, Garden City, New York.

Popa, S., Soto-Acosta, P., \& PerezGonzalez, D. (2018). An investigation of the effect of electronic business on financial performance of Spanish manufacturing SMEs. Technological Forecasting and Social Change, 136, 355-362.

Preacher, K.J., \& Hayes, A.F. (2008). Asymptotic and resampling strategies for assessing and comparing indirect effects in multiple mediator models. Behavior Research Methods, 40 (3), 879-891.

Sok, P., \& O'Cass, A. (2011). Achieving superior innovation-based performance outcomes in SMEs through innovation resource-capability complementarity. Industrial Marketing Management, 40 (8), 1285-1293.

Soto-Acosta, P., Popa, S., \& PalaciosMarqués, D. (2016). E-business, organizational innovation and firm performance in manufacturing SMEs: an empirical study in Spain. Technological and Economic Development of Economy, 22 (6), 885-904.

Storey, C., \& Kahn, K.B. (2010). The Role of Knowledge Management Strategies and Task Knowledge in Stimulating Service Innovation. Journal of Service Research, 13 (4), 397-410.

Sumbal, M.S., Tsui, E., \& See-to, E.W.K. (2017). Interrelationship between big data and knowledge management: an exploratory study in the oil and gas sector. Journal of Knowledge Management, 21 (1), 180-196.

Terziovski, M., \& Guerrero, J.-L. (2014). 
ISO 9000 quality system certification and its (2010). Reconsidering Baron and Kenny: impact on product and process innovation Myths and Truths about Mediation Analysis. performance. International Journal of Journal of Consumer Research, 37(2), 197Production Economics, 158 (C), 197-207. 206. Zhu, Z., Zhao, J., Tang, X., \& Zhang, Y. Urbinati, A., Bogers, M., Chiesa, V., \& (2015). Leveraging e-business process for Frattini, F. (2019). Creating and capturing business value: A layered structure value from Big Data: A multiple-case study perspective. Information \& Management, analysis of provider companies. 52(6), 679-691.

Technovation, 84-85, 21-36.

Van der Vorst, J.G.A.J., Van Dongen, S., Nouguier, S., \& Hilhorst, R. (2002). Ebusiness Initiatives in Food Supply Chains; Definition and Typology of Electronic Business Models. International Journal of Logistics Research and Applications, 5 (2), 119-138.

Venkitachalam, K., \& Willmott, H. (2017). Strategic knowledge managementInsights and pitfalls. International Journal of Information Management, 37 (4), 313-316.

Veselovská, L., Kožarova, M., \& Zavadsky, J. (2018). Relationship between information sharing and flexibility in management of enterprises in automotive industry: An empirical study. Serbian Journal of Management, 13 (2), 381-393.

West, J., \& Bogers, M. (2014). Leveraging External Sources of Innovation: A Review of Research on Open Innovation. Journal of Product Innovation Management, 31 (4), 814-831.

World Economic Forum. (2016). The Global Information Technology Report 2016: Innovating in the Digital Economy. Retrieved from http://www3.weforum.org/docs/GITR2016/ WEF_GITR_Full_Report.pdf

Zhao, J., Huang, W. V., \& Zhu, Z. (2008). An Empirical Study of E-Business Implementation Process in China. IEEE Transactions on Engineering Management, 55 (1), 134-147.

Zhao, X., Lynch Jr, J.G., \& Chen, Q. 